\title{
Investigating the moderating role of knowledge: The relationship between auditor's experience and ethical judgment
}

\author{
Muhammad Hamzah Idris \\ School of Economics Makassar (STIEM Bongaya) Indonesia \\ Hisnol Jamali \\ School of Economics Makassar (STIEM Bongaya) Indonesia \\ Herman Sjahruddin \\ School of Economics Makassar (STIEM Bongaya) Indonesia
}

\begin{abstract}
Based on ethical judgment, we examine the Auditor experience and ethical judgment: Examining the moderating role of knowledge. We hypothesize that the auditor's knowledge can be moderate the effect of auditor's experience on ethical judgment. Our research hypothesis was tested in a survey of 97 government auditors in South Sulawesi (Indonesia). Variance-based SEM techniques (structural equation models) with employs WarpPLS 6.0 was used to verify the hypothesis. The results of the study show that the auditor's knowledge acts as a quasi-moderator variable in explaining the relationship between auditor's experience and ethical judgment.
\end{abstract}

Keywords: auditor's experience, knowledge, ethical judgment

\section{INTRODUCTION}

The role of auditors in protecting company assets is one form of defense to prevent and detect fraud. Auditors are professionally qualified people with the experience and knowledge they have required to understand the company's internal and external processes. The most important thing is that the auditor can provide assurance that the internal control system in the company is in a position to reduce all types of risks and ensure that corporate governance is carried out effectively and efficiently so that the company's goals and objectives can be achieved (Alias et al., 2019). Social cognitive theory explores the performance of human behavior through three major factors: personal, behavioral, and environmental. Social cognitive theory explains that human behavior can be seen through three factors, namely personal, behavioral, and environmental factors. This theory provides a framework for explaining how one's moral processes that translate cognitive processes, moral instructions, and reactions related to ethical problems. Social cognitive theory does not consider the structure of moral rules as internal regulators that do not change, that destructive behavior can be accepted by individuals or society through a process of moral justification (Bandura, 1991; Sjahruddin \& Normijati, 2013).

Ethical judgment is the process of considering several alternatives and choosing the most ethical alternatives (Hunt \& Vitell, 1986). The views of other scholars state that ethical judgment is a decision that is both legally and morally acceptable to the wider community (Shockley, 2018). A high level of ethical consideration will further increase an individual's sensitivity to criticize events, problems and conflicts. Auditors with high ethical thinking capacity will be better at dealing with conflicts and ethical dilemmas and are more independent in making decisions related to ethical dilemmas (Ismail \& Yuhanis, 2018). The auditor analyzes the company's accounting information in the form of financial statements, this 
is done to obtain reliable financial statements, and one of the factors that cause low auditor credibility is accounting crime. As a result of these crimes, users of financial statements begin to question the accountant's professionalism as an independent party in assessing fairness of financial statements. The time pressure experienced by the auditor is an important one in producing effective audit judgment (Liu \& Zhang, 2008).

Weak legal aspects of financial crime can be seen by the lack of criminal prosecutions for accountants and auditors, the lawsuits given to them are only civil prosecution. Determination of penalties concentrated on civil prosecution raises concerns about whether the justice system makes these violators accountable for law and ethical standards (Fisher et al., 2013). In carrying out its work, the auditor must be objective and uphold the value of integrity, this is not easy because the auditor is vulnerable to the strong influence of people in the company (Suddaby et al., 2009), and is under pressure to follow the wishes of the government (Roussy, 2013). Political considerations can influence the activities of auditors who are potentially corrupt (Neu et al., 2013). Auditors who have indicated that ethical behavior is not good then these conditions will increase their level of acceptance of unethical behavior (Mirshekary \& Carr, 2015).

\section{Auditor's experience}

\section{LITERATURE REVIEW}

Experience as one of the variables widely used in various studies specifically experience can be measured by the time span that has been used for a job or task (job). The use of experience is based on the assumption that the tasks carried out repeatedly provide the opportunity to learn to do it the best. Specifically experience can be measured by the time span that has been used for a job or task. The use of experience is based on the assumption that the tasks carried out repeatedly provide an opportunity to learn to do the best so that experience can be used to improve the performance of decision making (Herliansyah \& Ilyas, 2006). The auditor's experience will grow further with the increase in audit experience. When auditors become more experienced, the auditor becomes aware of errors, auditors have fewer misconceptions about errors and auditors become aware of unusual errors (Tubbs, 1992).

Task-specific knowledge helps the performance of auditors who are experienced both in the components of the cue selection and cue weighting on the risk assessment (Bonner \& Lewis, 1990). Inexperienced auditors have a more significant error rate than experienced auditors (Abdolmohammadi \& Wright, 1987). Experienced auditors have more complete knowledge about financial statement errors, study error occurrences rates, organize knowledge about financial statements of errors over time, including during the transaction cycle (Libby \& Frederick, 1990). Experience and training generate knowledge combined with the ability to audit tasks. In other words, knowledge is gained through experience so that it can be said that between knowledge and performance are related (Bonner \& Lewis, 1990). Research in cognitive psychology also says that knowledge structures are the main factor that distinguishes between experts and novices. Auditors obtain special knowledge through training and experience (Bedard, 1989).

Experience provides accumulated knowledge that can help professionals to develop effective mental models for interpreting and integrating evidence in judgment. Therefore, experienced auditors have more knowledge and different memory structures so that they are expected to improve the quality of their judgment. The auditor's experience has a significant effect on the auditor's knowledge in carrying out his work (Haryanti, 2016). The auditor's experience uses measurements of Ziegenfuss \& Singhapakdi (1994) as measured by the number of years an auditor works as an auditor. Auditors with less than 1 year work experience are given a score 
of 1 , more than 1 year to 2 years are given a score of 2 , more than 2 years to 3 years are given a score of 3, more than 3 years to 4 years are given a score of 4 and auditor work experience more than 4 years given a score of 5

\section{Ethical judgment}

Process judgment depends on the arrival of information as a process of unfolds. The arrival of information not only affects choice but also influences the way the choice is made. In general there are two conditions for making the right judgment, namely using the right process and obtaining the right data or input. Ethical decisions (ethical decisions) are decisions that are both legally and morally acceptable to the wider community (Jones, 1991). The view of other scholars explains that ethical judgment is the process of considering several alternatives and choosing the most ethical alternatives (Hunt \& Vitell, 1986).

The main elements in ethical decision making (Jones, 1991) are: (1) a moral issue that states how far when someone takes action, if he is free to take action, it will cause harm or benefit for others. In other words, an action or decision taken will have consequences for others; (2) moral agent, namely someone who makes a moral decision; (3) the ethical decision itself is a decision that is legally and morally acceptable to the wider community. Ethical decisions are an interaction between individual factors and situational factors. Ethical decision making is highly dependent on individual factors such as ego strength, field dependence, locus of control, and situational factors such as immediate job context, organizational culture and characteristic of the work (Trevino, 1986).

Empirical facts show that there is an influence of experience on ethical judgment (Abdolmohammadi \& Wright, 1987). More experienced auditors show more complete knowledge in detecting financial statements errors. Auditors who have higher experience produce higher quality judgment and there is no difference between the quality judgments made by auditors in a strong ethical environment (Libby \& Frederick, 1990). Experienced auditors tend to be more conservative in dealing with situations of ethical dilemmas (Larkin, 2000). Empirical evidence shows that experience does not have a significant effect on ethical judgment (Hapsari, 2013; Yustrianthe, 2012; Januarti, 2011). The results obtained rebuttal from other researchers, that experience has a significant effect on ethical judgment (Putri \& Laksito, 2013; Rakhmalia, 2013). Ethical considerations in this study are the consideration of an auditor in determining opinions regarding the results of the audit when faced with an ethical dilemma. Variables of ethical considerations use instruments adopted from DeZoort \& Lord (1994). Include; materiality level, level of audit risk, and going concern are measured by five Likert scales, namely: (1) strongly disagree; (2) disagree; (3) neutral; (4) agree; (5) strongly agree.

\section{Auditor's Knowledge}

Knowledge obtained by someone is divided into three contexts: general knowledge domain, subspecialty knowledge, and world knowledge. General domain knowledge is knowledge gained by most people through learning and experience. The audit expert must have general domain knowledge, namely basic accounting and knowledge about auditing Subspecialty knowledge is also knowledge acquired through formal learning and experience but only for someone in a particular field (specialist). This knowledge relates to specific industries or clients obtained by someone who has experience about the specific audits of clients. World knowledge is knowledge gained by individual life experiences but is not only influenced by the same experience (Bonner \& Lewis, 1990). Knowledge is obtained through direct experience (prior judgment and performance feedback) or indirect (education). Knowledge becomes two categories, namely public knowledge and private knowledge. Public knowledge includes facts, 
theories and definitions of textbooks and journals while private knowledge consists of rules of thumb obtained through direct experience (Bedard, 1989).

Auditors who are more experienced on average do their jobs better than those who are less experienced and have more knowledge and abilities (Bonner \& Lewis, 1990). Knowledge of the frequency of errors obtained by accountants of the most experienced examiners through experience in examining financial statements is limited and accountants with the same level of experience have very different knowledge about the causes and consequences of errors (Ashton, 1991). Empirical evidence shows that auditor knowledge does not significantly influence Ethical Judgment (Suweknyo, 2016). These results are inconsistent with the findings of other researchers, that auditor knowledge has a significant effect on Ethical Judgment (Putri et al., 2016; Yendrawati \& Mukti, 2015; Rakhmalia, 2013). Ethical judgment is directly influenced by knowledge and indirectly influenced by experience and ability. Experience in forming an auditor becomes familiar with the situation and situation in each assignment because experience can help the auditor develop a more comprehensive knowledge structure so that experience will increase the knowledge of an auditor. Knowledge possessed by auditors can help him to make appropriate judgments and decisions by weighting the evidence they obtain. Thus, if an auditor has experience, it will increase knowledge, which in turn will affect the judgment he produces (Libby \& Lufty, 1993).

Measurement of auditor knowledge in this study is knowledge originating from subspecialty knowledge, namely knowledge obtained through audit assignments (Bonner \& Lewis, 1990) as measured by the number of audit assignments received by an auditor. Auditors who were never given the task of auditing were given a score of 1 , had been given the task of auditing 1 time given a score of 2 , had been given audit assignments 2 to 5 times were given a score of 3 , had been given audit assignments 5 to 10 times were given a score of 4 , dam had been given the task of auditing more than 10 times were given a score of 5 .

\section{RESEARCH METHODS}

This study used a scientific method approach. The collected empirical data was processed statistically using a variance-based SEM (structural equation model) technique through WarpPLS 6.0 to test the proposed research hypothesis. This study focuses on disclosing causal relationships between variables. The population in this study is the Audit Board of the Republic of Indonesia in South Sulawesi. The reason for choosing auditors in the Audit Board of the Republic of Indonesia in South Sulawesi is that all samples are homogeneous, so that the area does not affect. The number of questionnaires sent was 143 questionnaires. Questionnaires that returned within the specified time period were $97(97 / 143=67.83 \%$ response rate level) and only 97 questionnaires could be used.

\section{Participants'}

\section{RESULTS}

The Participants' identity in form of gender, age, education level and work period, is presented to find out the number of frequencies and the percentage of respondents who are representative in giving responses 
Table 1. Participants

\begin{tabular}{|c|c|c|c|}
\hline & Characteristics & $\begin{array}{c}\text { Frequency } \\
\quad(\mathrm{n}=97)\end{array}$ & Percent (\%) \\
\hline \multirow{3}{*}{ Gender } & Male & 83 & 85,57 \\
\hline & Female & 14 & 14,43 \\
\hline & $36-40$ & 9 & 9,28 \\
\hline \multirow{3}{*}{ Age (years) } & $41-45$ & 21 & 21,65 \\
\hline & $46-50$ & 39 & 40,21 \\
\hline & $51-55$ & 28 & 28,86 \\
\hline \multirow{3}{*}{ Job Tenure } & $\leq 10$ & 11 & 11,34 \\
\hline & $11-15$ & 37 & 38,14 \\
\hline & $\geq 16$ & 49 & 50,52 \\
\hline \multirow{3}{*}{ Educational level } & Graduate degree program & 63 & 64,95 \\
\hline & Masters program & 27 & 27,84 \\
\hline & Doctoral program & 7 & 7,22 \\
\hline
\end{tabular}

The table shows that based on gender, the frequency of respondents were characterized by 83 male auditors $(85.57 \%)$ while the rest were indicated by 14 female auditors $(14.43 \%)$. The dominance of male auditors is due to several reasons that auditors with male gender have better abilities in addressing personal problems faced in the completion of work, because men tend to have high emotions but they can be neutralized quickly in carrying out their functions as auditor. Then men tend to have higher aggressiveness so they dare to express their feelings and ideas in an assertive (assertive) and initiative in work. Generally respondents have age in the age group 46-50 were 39 (40.21\%). This condition explains that auditors have high work ability in carrying out their activities. Age at range 46-50 years is classified as productive age that auditor's work ability will be higher compared to someone who is in non- productive age. This is because in productive age a person has motivation and enthusiasm and a strong force so that he is able to carry out his function as an auditor well.

Auditor's job tenure in the 11-15 year job tenure group was 37 (38.14\%). Job tenure in groups of 11-15 years is the result of absorption from various auditor activities, so that they are able to grow the skills that arise in the actions they take in completing work. Auditors who have worked for a long time or carry out their profession have various work experiences related to their field of work. Finally for the education level the majority of auditors are in the 63 graduate degree programs (64.95\%). That the development of financial management transparency as one of the functions of auditors must be accompanied by the development of human resources in various aspects, that with the education they have at the level of the Graduate degree program it is considered sufficient to carry out the functions of the auditor.

\section{Goodness of fit model}

The p-value for average path coefficient (APC) and ARS and the Average R-squared (ARS) value must be $<0.05$. In addition, Average full collinearity VIF (AFVIF) as a multicollinearity indicator must be $<5$. 
Table 2. Goodness of fit model

\begin{tabular}{|c|c|c|}
\hline Measurement & Model 1 & Model 2 \\
\hline Average path coefficient (APC) & $0.347 \rightarrow \mathrm{P}<0.001$ & $0.376 \rightarrow \mathrm{P}<0.001$ \\
\hline Average R-squared (ARS) & $0.219 \rightarrow \mathrm{P}=0.006$ & $0.237 \rightarrow \mathrm{P}=0.004$ \\
\hline $\begin{array}{l}\text { Average adjusted R-squared } \\
\text { (AARS) }\end{array}$ & $0.203 \rightarrow P=0.009$ & $0.222 \rightarrow \mathrm{P}=0.006$ \\
\hline Average block VIF (AVIF) & $\begin{array}{l}1.372 \text {, acceptable if }<=5 \text {, ideally } \\
<=3.3\end{array}$ & $\begin{array}{l}\text { 1.536, acceptable if }<=5 \text {, ideally } \\
<=3.3\end{array}$ \\
\hline Average block VIF (AFVIF) & $\begin{array}{l}1.226 \text {, acceptable if }<=5 \text {, ideally } \\
<=3.3\end{array}$ & $\begin{array}{l}1.341 \text {, acceptable if }<=5 \text {, ideally } \\
<=3.3\end{array}$ \\
\hline Tenenhaus GoF (GoF) & 0.439 & 0.470 \\
\hline
\end{tabular}

The results show that the Goodness of fit models in models 1 and 2 have been fulfilled so that they can implemented for the next step (Kock, 2011; Hasanuddin \& Sjahruddin, 2017).

Table 3. Combined Loading and cross-loadings (Model 1)

\begin{tabular}{lccccccc}
\hline Constructs & Expert & Knowld & Judg & Knowld*Expert & Type (a & SE & P-value \\
\hline PGLA & $(1.000)$ & 0.000 & 0.000 & 0.000 & Reflective & 0.077 & $<0.001$ \\
PGTA & 0.000 & $(1.000)$ & 0.000 & 0.000 & Reflective & 0.077 & $<0.001$ \\
TM & 0.327 & 0.389 & $(0.761)$ & 0.292 & Reflective & 0.085 & $<0.001$ \\
TRA & 0.107 & -0.029 & $(0.913)$ & -0.001 & Reflective & 0.079 & $<0.001$ \\
GC & -0.553 & -0.407 & $(0.567)$ & -0.338 & Reflective & 0.087 & $<0.001$ \\
PGTA*PGLA & 0.000 & 0.000 & 0.000 & $(1.000)$ & Reflective & 0.077 & $<0.001$ \\
\hline
\end{tabular}

Measurement model or outer model, namely validity and construct reliability, this output is used by researchers to report the results of convergent validity testing of measurement instruments (questionnaires) In Table 3. Combined Loading and cross-loadings there are still constructs whose convergence validity is $<0.70$ (i.e. GC $\rightarrow 0.567$, although p-value $<0.05$ ) so it must be excluded from the model.

Table 4. Combined Loading and cross-loadings (Model 2)

\begin{tabular}{lccccccc}
\hline Constructs & Expert & Knowld & Judg & Knowld*Expert & Type (a & SE & P-value \\
\hline PGLA & $(1.000)$ & 0.000 & 0.000 & 0.000 & Reflective & 0.077 & $<0.001$ \\
PGTA & 0.000 & $(1.000)$ & 0.000 & 0.000 & Reflective & 0.077 & $<0.001$ \\
TM & -0.011 & 0.133 & $(0.856)$ & 0.105 & Reflective & 0.080 & $<0.001$ \\
TRA & 0.011 & -0.133 & $(0.856)$ & -0.105 & Reflective & 0.080 & $<0.001$ \\
PGTA*PGLA & 0.000 & 0.000 & 0.000 & -1.000 & Reflective & 0.077 & $<0.001$ \\
\hline
\end{tabular}

The test in Table 4 shows that the criteria for convergent validity in model 1 have not (i.e. GC $\rightarrow 0.567$ ) are met and for model 2 it has been fulfilled because it meets the requirements, convergent validity is $>0.70$ and significant ( $p$-value $<0.05$ ) so model 2 is used for the next stage (Hair et al., 2013).

\section{Discriminant validity}

The test of discriminant validity is proven by the results of the latent variable correlations. This output reports the correlation coefficient between latent variables. The criteria used are square roots average variance extracted (AVE), which is a diagonal column with parentheses that must be higher than the correlation between latent variables in the same column (above or below) (Sholihin \& Dwi, 2013). 
Table 5. Correlations among l.vs. with sq. rts. of Aves (Model 2)

\begin{tabular}{lcccc}
\hline \multicolumn{1}{c}{ Constructs } & Expert & Knowld & Judg & Knowld*Expert \\
\hline Expert & $(1.000)$ & 0.225 & 0.443 & -0.292 \\
Knowld & 0.225 & $(1.000)$ & 0.456 & 0.065 \\
Judg & 0.443 & 0.456 & $(0.856)$ & 0.042 \\
Knowld*Expert & -0.292 & 0.065 & 0.042 & $(1.000)$ \\
\hline
\end{tabular}

The table shows that the validity discriminant has been fulfilled, which can be seen from the AVE root in the diagonal column greater than the correlation between constructs in the same column. The cross-loading results are indicative of fulfilling the criteria for discriminant validity.

\section{Construct reliability}

The coefficient of determination (R-squared) that shows what percentage of the variance of the construct of an endogenous / criterion can be explained by the construct of the hypothesized effect. The higher R-squared shows a good model. From the results of the latent variable coefficient, the R-squared knowledge auditor $\rightarrow 0.092$ means that the variance of knowledge auditors can be explained only by $9.20 \%$ by the experience auditor variance while R-squared for constructing ethical judgment $\rightarrow 0.382$ indicates that the variance of ethical judgment can be explained at $38.20 \%$ by the auditor experience variance.

The test results of construct reliability can be shown by the output coefficient latent variable, as in the following table:

Table 6. Latent variable coefficient (Model 2)

\begin{tabular}{lcccc}
\hline \multicolumn{1}{c}{ Measurement } & Expert & Knowld & Judg & Knowld*Expert \\
\hline R-squared coefficients & & 0.092 & 0.382 & \\
Adjusted R-squared coefficients & & 0.083 & 0.362 & \\
Composite reliability coefficients & 1.000 & 1.000 & 0.846 & 1.000 \\
Cronbach's alpha coefficients & 1.000 & 1.000 & 0.636 & 1.000 \\
Average variances extracted & 1.000 & 1.000 & 0.733 & 1.000 \\
Full collinearity VIFs & 1.419 & 1.269 & 1.532 & 1.144 \\
Q-squared coefficients & & 0.094 & 0.381 & \\
Minimum and maximum values & -2.191 & -1.963 & -2.319 & -1.774 \\
& 0.934 & 1.883 & 1.263 & 3.517 \\
Medians (top) and modes (bottom) & -0.628 & -0.04 & -0.127 & -0.171 \\
Skewness (top) and exc. kurtosis (bottom) & 0.934 & -0.04 & 1.263 & -0.171 \\
coefficients & -0.588 & 0.029 & -0.441 & 1.648 \\
& -0.615 & 0.728 & -0.543 & 4.496 \\
\hline
\end{tabular}

The composite reliability and cronbach alpha values have met the reliability requirements of $>$ 0.70 . The output above also shows that average variance extracted (AVE) $>0.50$, which means it meets the requirements of convergent validity (Sholihin \& Dwi, 2013). Full collinearity (VIF) is the result of full collinearity testing which includes vertical and lateral multicollinearity. Lateral collinearity is the colinearity between the predictive latent variables and the criterion. Lateral collinearity is often ignored when it can cause research results to be biased. Full collinearity (VIF) in this study was lower than 3.3, indicating that the model is free from problems of vertical, lateral, and commond bias method. (Kock, 2013).

The Q-squared is a non-parametric measure obtained through blindfolding algorithms and used to research predictive validity or relevance of a set of predictive latent variables on the criterion variable. Output shows Q-squared greater than zero, knowledge auditor $\rightarrow 0.094$ and 
ethical judgment $\rightarrow 0.381$ means that model estimation shows good predictive validity. Overall, the results of the measurement model (outer model) of the reflective construct meet the requirements.

\section{The hypothesis testing}

The results of testing models and hypotheses show that, among 3 (three) causalities between variables (direct influence) and 1 (one) for the role of moderation (indirect effect) built into this model, the overall hypothesis proposed is proven empirical. This can be shown in Table 7:

Table 7. Path coefficients $\rightarrow$ P-values (Model 2)

\begin{tabular}{|c|c|c|c|c|}
\hline \multicolumn{5}{|c|}{ Path coefficients $\rightarrow$ P-values } \\
\hline Variables & Expert & Knowld & Judg & Knowld *Expert \\
\hline \multicolumn{5}{|l|}{ Expert } \\
\hline Knowld & $0.304 \rightarrow<0.001$ & & & \\
\hline Judg & $0.425 \rightarrow<0.001$ & $0.533 \rightarrow<0.001$ & & $-0.242 \rightarrow 0.006$ \\
\hline Knowld *Expert & & & & \\
\hline
\end{tabular}

\section{Effect of auditor experience on auditor knowledge}

Effect of auditor experience on work enthusiasm can be proven by standardized path coefficient (beta / standardized path coefficient) $\rightarrow 0.304$ with positive direction. A positive signed beta / standardized path coefficient explains that a high auditor experience is proven to increase auditor knowledge. Then it can be proved by p-value $\rightarrow 0.001<0.05$. The results of hypothesis testing prove that the auditor's experience has a significant positive effect on the auditor's knowledge, it can be concluded that the auditor's experience in carrying out his duties and functions is high in the same direction and real to the auditor's knowledge. Based on these results, the hypothesis proposed (H1) experience significant positive effect on auditor knowledge can be accepted or supported by empirical facts.

The higher the experience of an auditor will increase his knowledge because experience is closely related to knowledge. An auditor who has more experience will also increase his knowledge so that it will provide better results than those who do not have sufficient knowledge in their duties. Auditors who have experience will show higher skepticism than those who are less experienced. Experience provides accumulated knowledge that can help professionals to develop effective mental models for interpreting and integrating evidence in judgment. The results of this study are relevant evidence from previous researchers that auditor knowledge is derived from experience where more experienced auditors will show a higher attitude of professional skepticism than inexperienced auditors (Han et al., 2011). Experience and training generate knowledge combined with the ability to audit tasks. In other words, knowledge is gained through experience so that it can be said that between knowledge and performance are related (Bonner \& Lewis, 1990). Knowledge structure is the main factor that distinguishes between expert and novice.

Auditors obtain special knowledge through training and experience (Bedard, 1989). Experienced auditors have more complete knowledge about financial statement errors, study error rates, organize knowledge about financial statements of errors over time, including during the transaction cycle (Libby \& Frederick, 1990). Knowledge structure is the main factor that distinguishes between expert and novice. Auditors obtain special knowledge through training and experience (Bedard, 1989). Experienced auditors have more knowledge and 
different memory structures so that they are expected to improve the quality of their judgment. The auditor's experience has a significant effect on the auditor's knowledge in carrying out his work (Haryanti, 2016).

\section{Effect of auditor experience on ethical judgment}

Effect of auditor experience in ethical judgment can be proved by standardized path coefficient (beta / standardized path coefficient) $\rightarrow 0.425$ in a positive direction. A positive signed beta / standardized path coefficient explains that a high auditor experience is proven to increase the ethical judgment auditor's. Then it can be proved by p-value $\rightarrow 0.001<0.05$. The results of hypothesis testing prove that the auditor's experience has a significant positive effect on the ethical judgment auditor's, it can be concluded that the auditor's experience in carrying out his duties and functions is high in the direction and direction of the ethical judgment auditor's. Based on these results, the hypothesis proposed $\left(\mathrm{H}_{2}\right)$ experience significant positive effect on the ethical judgment can be accepted or supported by empirical facts.

The higher the experience of an auditor will increase ethical considerations because the tasks carried out repeatedly provide opportunities to do the best so that experience can improve the performance of decision making. An auditor who has sufficient audit experience will not have the same view of the case faced, compared to a novice auditor who does not have enough experience. Auditors who already have more work experience enable the development of a higher level of ethical judgment because while working as an auditor are often faced with actions related to ethical behavior so that the more often an auditor faces an ethical dilemma it will help the auditor's sensitivity to criticize events, problems and conflicts that occur which will ultimately be better ethical considerations.

The results of this study are relevant to the findings by Uyar \& Gungormus (2011) that experience provides an accumulation of knowledge that can help professionals to develop effective mental models to interpret and integrate evidence in carrying out judgment tasks. There is an influence of experience on ethical judgment (Abdolmohammadi \& Wright, 1987). Auditors who have higher experience produce higher quality judgment (Libby \& Frederick, 1990; Putri \& Laksito, 2013; Rakhmalia, 2013). The results of this study refute the findings of other researchers that experience does not significantly influence ethical judgment (Hapsari, 2013; Yustrianthe, 2012; Januarti, 2011).

\section{Effect of auditor knowledge on ethical judgment}

Effect of auditor knowledge on ethical judgment the auditor can be proven by standardized path coefficient (beta / standardized path coefficient) $\rightarrow 0.533$ with a positive direction. A positive signed beta / standardized path coefficient explains that a high auditor's knowledge is proven to increase the ethical judgment auditor's. Then it can be proved by p-value $\rightarrow 0.001$ $<0.05$. The results of hypothesis testing prove that the auditor's knowledge has a significant positive effect on the ethical judgment auditor's, it can be concluded that the auditor's knowledge in carrying out his duties and functions is high in the direction and direction of the ethical judgment auditor's. Based on these results, the hypothesis proposed $\left(\mathrm{H}_{3}\right)$ Auditor's knowledge positive significant effect on the ethical judgment can be accepted or supported by empirical facts.

Knowledge gained from experience can increase the auditor's ability to solve a problem by giving the auditor the ability to distinguish and analyze information. The difference in knowledge between auditors will affect the way the auditor completes a job. The auditor can complete a job effectively if supported by the knowledge he has. When the auditor is faced with an ethical dilemma, the individual will consider it cognitively in his mind. Knowledge gained 
from experience can improve the ability of a person to solve a problem by giving individuals the ability to distinguish and analyze information. The difference in knowledge between auditors will affect the way the auditor completes a job. An auditor will be able to complete a job effectively if supported by the knowledge he has. Auditors who have high knowledge will further increase the sensitivity of an individual to criticize events, problems and conflicts so that knowledgeable auditors face conflict and ethical dilemmas more independently in making decisions related to ethical dilemmas (Hasanuddin \& Sjahruddin, 2017). The results of this study refute the findings of previous researchers, that auditor knowledge does not significantly influence Ethical Judgment (Suweknyo, 2016). These results are inconsistent with the findings of other researchers, that auditor knowledge has a significant effect on Ethical Judgment (Rakhmalia, 2013; Schmidt, 2014; Yendrawati \& Mukti, 2015; Putri et al., 2016).

\section{The moderating role of knowledge in explaining the effect of auditor experience on ethical judgment}

Interaction between auditor experience and knowledge results in a high level of auditing experience so that it has an impact on the higher ethical judgment auditor's. The moderating role of knowledge can be evidenced by the standardized path coefficient (beta / standardized path coefficient) $\rightarrow-0.242$ with a negative direction. Negatively marked beta / standardized path coefficient explains that the government is required to constantly improve the auditor's experience and auditor knowledge is proven to improve the ethical judgment auditor's. Then it can be proved by p-value $\rightarrow 0.006<0.05$. Hypothesis testing results prove that the auditor's knowledge as a moderating variable is able to have a significant positive effect in explaining the effect of the auditor's experience on the auditor's ethical judgment, based on the type, the auditor's knowledge variable in this study is declared a quasi-moderator. The role of auditor's knowledge in carrying out its duties and functions is high in the direction and real in explaining the contribution of experience to the ethical judgment auditor's. Based on these results, the hypothesis proposed $\left(\mathrm{H}_{4}\right)$ auditor's knowledge acts as a moderator in explaining the effect of experience on the ethical judgment can be accepted or supported by empirical facts.

The experience of forming an auditor becomes familiar with the situation and situation in each assignment because experience can help the auditor develop a more comprehensive knowledge structure so that experience will increase the knowledge of an auditor. Knowledge possessed by auditors can help him to make appropriate judgments and decisions by weighting the evidence they obtain. Thus, an auditor who has experience will increase his knowledge which will ultimately increase his ethical considerations. This study is relevant to the findings Libby \& Luft (1993) that judgment is directly influenced by knowledge and indirectly influenced by experience and ability. Consistent with the findings of other researchers, that auditor knowledge has a significant effect on Ethical Judgment (Putri et al., 2016; Yendrawati \& Mukti, 2015; Rakhmalia, 2013). These results are inconsistent with the findings of other researchers that auditor knowledge does not significantly influence Ethical Judgment (Suweknyo, 2016). Experience in forming an auditor becomes familiar with the situation and situation in each assignment because experience can help the auditor develop a more comprehensive knowledge structure so that experience will increase the knowledge of an auditor. Knowledge possessed by auditors can help him to make appropriate judgments and decisions by weighting the evidence they obtain. Thus, if an auditor has experience, it will increase knowledge, which in turn will affect the ethical judgments that result from it.

\section{CONCLUSION AND DISCUSSION}

This study has broad implications for various parties related to the accounting profession; the results of this study provide evidence that experience makes a positive contribution in increasing auditor knowledge and auditor's ethical judgment. That is, the higher the auditor's 
experience, the higher his ethical judgment will be. This study also succeeded in proving that auditor knowledge is a quasi-moderator in explaining the effect of auditor experience on ethical judgment. This indicates that the increase in knowledge is needed by auditors to increase the level of ethical considerations so that it is expected that having knowledge that is better able to recognize ethical problems better so as to encourage auditors to behave ethically.

The results of this study are important to encourage the direction of behavioral accounting research as an effort to develop scientific knowledge in behavioral accounting, especially auditing to consider individual competencies which include experience and knowledge as important determinants of auditor ethical behavior because auditors will be trusted by the public if they have ethical considerations in carrying out his profession. This study has limitations in analyzing the findings because the analysis unit used is limited to the Audit Board of the Republic of Indonesia.

\section{References}

Abdolmohammadi, M., \& Wright, A. (1987). An examination of the effects of experience and task complexity on audit judgments. Accounting Review, 1-13.

Alias, NF, Nawawi, A., \& Copy, ASAP (2019). Internal Auditors' Compliance to Code of Ethics: Empirical Findings from Malaysian Government-Linked Companies. Journal of Financial Crime, (just-accepted), 00-00.

Ashton, AH (1991). Experience and error frequency knowledge as potential determinants of audit expertise. Accounting Review, 218-239.

Bandura, A. (1991). Social cognitive theory of self-regulation. Organizational behavior and human decision processes, 50 (2), 248-287.

Bedard, J. (1989). Expertise in auditing: Myth or reality ?. Accounting, Organizations and Society, 14 (1-2), 113131.

Bonner, SE, \& Lewis, BL (1990). Determinants of auditor expertise.Journal of accounting research, 1-20.

Chi, W., Myers, LA, Omer, TC, \& Xie, H. (2017). The effects of audit pre-client and client-specific partners experience on audit quality and perceptions of audit quality. Review of Accounting Studies, 22 (1), 361-391.

DeZoort, FT, \& Lord, AT (1994). An investigation of the obedience of pressure effects on auditors' judgments. Behavioral Research in Accounting, 6 (1), 1-30.

Dunn, P., \& Sainty, B. (2019). Professionalism in accounting: a five-factor model of ethical decision-making. Social Responsibility Journal.

Fisher, J., Blottiax, M., Daniel, S., Oliveria, H., Green, D., Osaka, O., \& Trakkidi, A. (2013). The global financial crisis: the case for a stronger criminal response. Law and Financial Markets Review, 7 (3), 159-166

Gissel, JL, \& Johnstone, KM (2016). Information sharing during the auditors' fraud brainstorming: Effects of psychological safety and auditor knowledge. Auditing: A Journal of Practice \& Theory, 36 (2), 87-110.

Hair, JF, Ringle, CM, \& Sarstedt, M. (2013). Structural equation modeling of least least squares: Rigorous applications, better results and higher acceptance.

Han, J., Jamal, K., \& Tan, HT (2011). Auditors' overconfidence in predicting the technical knowledge of superiors and subordinates. Auditing: A Journal of Practice \& Theory, 30 (1), 101-119

Hapsari, NN (2013). Effect of Auditor Experience and Ethical Orientation on Ethical Decisions of State Auditors with Professional Commitments as Intervening Variables. El Muhasaba: Journal of Accounting, 2 (2).

Haryanti, CS (2016). The Effect of Experience and Auditor Training on the Knowledge Structure of Auditor Errors.

Hasanuddin, R., \& Sjahruddin, H. (2017). The Structure of Emotional Intelligence, Spiritual Intelligence and Its Relationship with Work Enthusiasm and Auditor Performance. World Journal of Business and Management, 3 (1), 67.

Herliansyah, Y., \& Ilyas, M. (2006). Effects of Auditor Experience on the Use of Evidence Irrelevant in Auditor Judgment. SNA 9 Padang, 23-26.

Hunt, SD, \& Vitell, S. (1986). A general theory of marketing ethics. Journal of macromarketing, 6 (1), 5-16. 
Idris, M. H., Jamali, H., \& Sjahruddin, H. (2019). Investigating the moderating role of knowledge: The relationship between auditor's experience and ethical judgment. Advances in Social Sciences Research Journal, 6(2) 491-503.

Ismail, S., \& Yuhanis, N. (2018). Determinants of ethical work behavior from Malaysian public sector auditors. Asia-Pacific Journal of Business Administration, 10 (1), 21-34.

Januarti, I. (2011). Analysis of the Effects of Auditor Experience, Professional Commitment, Ethical Orientation and Value of Organizational Ethics on Ethical Perception and Consideration (Auditor of the Indonesian Audit Board). Paper Presented at the National Symposium on Accounting XIV, Aceh.

Jones, JJ (1991). Earnings management during import relief investigations. Journal of accounting research, 193228.

Kock, N. (2011). Using WarpPLS in e-collaboration studies: Mediating effects, control and second order variables, and algorithm choices. International Journal of e-Collaboration (IJeC), 7 (3), 1-13.

Larkin, JM (2000). The ability of internal auditors to identify ethical dilemmas. Journal of Business Ethics, 23 (4), 401-409.

Libby, R., \& Frederick, DM (1990). Experience and the ability to explain audit findings. Journal of Accounting Research, 348-367.

Libby, R., \& Luft, J. (1993). Determinants of judgment performance in accounting settings: Ability, knowledge, motivation, and environment. Accounting, organizations and society, 18 (5), 425-450.

Liu, Chengli, \& Zhang, Jixun. (2008). Time pressure, accountability and audit judgment performance: an experimental study. China Account. Rev, 4, 405-424.

Miko, NU, \& Kamardin, H. (2015). Impact of audit committee and audit quality on preventing earnings management in the 2011 pre-and post-Nigerian corporate governance code. Procedia-Social and Behavioral Sciences, 172, 651-657

Mirshekary, S., \& Carr, R. (2015). Effects of exposure practices on personal attitudes of accountants in small accounting firms. Journal of Management \& Organization, 21 (1), 98-106.

Morales, J., Gendron, Y., \& Guenin-Paracini, H. (2014). The construction of the risky individual and criminal organization: A genealogy of the fraud triangle. Accounting, Organizations and Society, 39 (3), 170-194.

Neu, D., Everett, J., \& Rahaman, US (2013). Internal auditing and corruption within the government: The case of the Canadian Sponsorship Program. Contemporary Accounting Research, 30 (3), 1223-1250.

Putri, AR, Nasir, A., \& Safitri, D. (2016). Effect of Time Budget Pressure, Task Complexity, Auditor Knowledge, and Auditor's Experience on Audit Judgment (Case Study of Kap in Pekanbaru, Batam, and Padang). Student Online Journal (JOM) in Economics, 4 (1), 1282-1294.

Putri, PA, \& Laksito, H. (2013). The influence of ethical environment, auditor experience and compliance pressure on audit judgment quality. Diponegoro Journal of Accounting, 383-393.

Rakhmalia, A. (2013). Effect of Knowledge, Experience and Ethical Orientation on the Audit Judgment with Ethical Decision Making as Intervening Variables (Study at the Public Accounting Firm in Central Java) (Doctoral dissertation, Semarang State University).

Republic of Indonesia. (2006). Minister of Home Affairs Regulation Number 13 of 2006 concerning Regional Financial Management.

Roussy, M. (2013). Roles' internal auditors: From watchdogs to helpers and protectors of the top managers. Critical Perspectives on Accounting, 24 (7-8), 550-571.

Schmidt, RN (2014). The effects of auditors' accessibility to "tone at the top" knowledge on audit judgments. Behavioral Research in Accounting, 26 (2), 73-96.

Shockley, CD (2018). Ethical Decision-Making and Internal and External Auditors: A Quantitative Study (Doctoral dissertation, Capella University).

Sholihin, M., \& Ratmono, D. (2013). SEM-PLS analysis with WarpPLS 3.0 for Nonlinear Relationships in Social and Business Research. Yogyakarta: CV. Andi Offset.

Siriwardane, HP, Kin Hoi Hu, B., \& Low, KY (2014). Important Skills, Knowledge, and Attitudes for Day Auditors. International journal of auditing, 18 (3), 193-205.

Sjahruddin, H., \& Normijati, A. A. S. (2013). Personality effect on organizational citizenship behavior (OCB): trust in manager and organizational commitment mediator of organizational justice in Makassar City Hospitals (Indonesia). European Journal of Business and Management, 5(9), 95-104. 
Suddaby, R., Gendron, Y., \& Lam, H. (2009). The organizational context of professionalism in accounting. Accounting, organizations and society, 34 (3-4), 409-427.

Suweknyo, A. (2016). Effects of Compliance Pressure, Task Complexity, Knowledge, Ethical Perception and SelfEfficacy on Audit Judgment (Empirical Study in Surakarta and Yogyakarta Public Accounting Firm) (Doctoral dissertation, Muhammadiyah University Surakarta).

Trevino, KT (1986), "Ethical decision making in organizations: a person-situation interaction model", Academy of Management Review, Vol. 11 No. 3

Tubbs, RM (1992). The effect of experience on the auditor's organization and amount of knowledge. Accounting Review, 783-801.

Uyar, A., \& Gungormus, AH (2011). Professional knowledge and skills required for accounting majors who become auditors: Perceptions of external auditors. Business and Economics Research Journal, 2 (3), 33.

Yendrawati, R., \& Mukti, DK (2015). Effect of gender, auditor experience, task complexity, obedience pressure, work ability and auditor knowledge on judgment audits. Asian Journal of Innovation and Entrepreneurship, 4 (01), 1-8

Yustrianthe, RH (2012). Several factors that influence audit judgment of government auditors. Journal of Dynamics of Accounting, 4 (2).

Ziegenfuss, DE, \& Singhapakdi, A. (1994). Professional values and the ethical perceptions of internal auditors. Managerial Auditing Journal, 9 (1), 34-44. 